\title{
Artigos
}

Persp. Teol. 33 (2001) 309-330

\section{REPENSAR O MAL NA NOVA SITUAÇÃO SECULAR}

Andrés Torres Queiruga

\section{Um mistério perene numa situação} nova: "ponerologia" e "pisteodicéia"

O mal - punho de ferro no rosto da humanidade - é um mistério inescrutável. Nunca atingiremos o fundo do seu horror nem conseguiremos mergulhar até o fim da sua profundidade. Mas isso não significa que não deva ser pensado, como tantas vezes se disse e se repete. Ou que a maneira de abordá-lo seja imutável. 0 mistério não é algo absurdo e contraditório. Pode, portanto, ser pensado. E não fazê-lo seria apenas um pretexto para a inércia mental. 0 mistério é algo que não tem fundo. Eis por que exige sem cessar novas aproximações, insuficientes sempre, mas necessárias. Cabe a nós mostrar a coerência de tais aproximações. Por isso cada época tem que buscar a sua resposta, procurando estar à altura dos desafios concretos.

Essa dupla convicção é o ponto de partida destas reflexões. É pouco o que podemos dizer acerca do mal. Mas o que dizemos tem que estar baseado em razões capazes de resistir à crítica e de mostrar a sua coerência interna, sem recorrer apressadamente ao "mistério" nem refugiar-se em disfarçadas trincheiras "fideístas". E, por outro lado, o mal é histórico. Em cada tempo e cultura se apresenta com rostos diferentes. Concretamente, a irrupção da modernidade significou uma mudança tão profunda que implica um questionamento radical da fé 
em Deus. O mal é "como rocha do ateísmo". Mas, ao mesmo tempo, essa situação oferece também novas possibilidades de resposta.

Esta polaridade permite aceitar o diagnóstico kantiano do fracasso da teodicéia ${ }^{1}$, mas com uma condição indispensável: não se trata do fracasso da teodicéia como tal e sim da teodicéia tradicional. De modo que não é necessário resignar-se acriticamente nem ao ateísmo, nem ao fideísmo ou à incoerência lógica. Aí reside a questão decisiva: não se trata de uma mudança pontual ou isolada. $O$ fracasso da teodicéia se explica pela mudança de todo o contexto cultural e religioso dentro do qual estava situada. A questão consiste então em modificar a maneira de formular o problema de acordo com as novas exigências. De modo geral, os que reconhecem a mudança não podem mais aceitar como válida a solução até então vigente, enquanto que a tendência dos que continuam a defender a tradição é não enxergar a mudança.

É importante, pois, compreender a mudança porque disso depende a nova maneira de propor o problema. A essência dessa mudança poderia ser sintetizada em dois conceitos: a secularidade que, por sua vez, deriva de outro ainda mais radical: a autonomia. De fato, 0 que há de mais válido e irreversível na modernidade é a descoberta do caráter autônomo dos diferentes níveis ou estratos do nosso mundo, que é um mundo regido pelas suas leis intrínsecas e não pode mais ser considerado como submetido a contínuas interferências extramundanas, sejam elas divinas ou angélicas (no caso do bem) ou demoníacas e infernais (no caso do mal).

Rudolf Bultmann, com o seu programa de desmitologização, chamou a atenção para a importância deste fato na leitura da Bíblia. (Os seus possíveis exageros e o problema da "privatização", que é diferente, não deveriam servir de pretexto para recusar o que a sua proposta contém de verdade inegável). A teologia precisa levar muito a sério essa questão para repensar tudo o que diz respeito à atuação de Deus no mundo. A frase que Laplace teria dito a Napoleão a propósito da astronomia ("senhor, eu não preciso dessa hipótese"), vale a seu modo para a física, a biologia e a psicologia. Mesmo a moral é reconhecida hoje com crescente unanimidade como autônoma.

Não é difícil perceber a incidência dessa questão no problema do mal. No século XIV. a peste negra desencadeou rogativas e procissões de pessoas que se flagelavam; no século XXI a Aids é abordada como uma questão política e de laboratórios. Tanto uma como a outra são um "mal”. Mas agora o problema "secularizou-se", i.é. aparece, de

${ }^{1}$ E. KANT, Das Misslingen aller philosophischen Versuche in der Theodizee, A 202 , Band XI, editado por W. WEISCHEDEL, Frankfurt a. M., 1978, 2a ed., pp. 105-124. 
maneira direta e imediata, como um problema humano que afeta igualmente os que têm fé e os ateus e exige de todos uma reposta. 0 problema, portanto, é comum embora as respostas possam ser diferentes. Tanto a atéia quanto a religiosa podem ser resposta. Por isso, em princípio, as duas têm os mesmos direitos e as mesmas obrigações: mostrar em que razões se apoiam e responder às objeções que Ihes possam ser feitas.

Esse é um sério desafio tanto para a religião quanto para os seus críticos. A religião, como já observara Kant, diante de uma razão crítica que já saiu da "culpável menoridade", não pode refugiar-se no prestígio da sua "santidade" para continuar encobrindo a evidência da contradição lógica ${ }^{2}$. Os críticos da religião devem reconhecer que, uma vez proclamada a autonomia do mundo, o mal não pode ser-lhe simplesmente extrínseco; atribuir o mal, sem mais e de maneira imediata, a Deus ou ao diabo equivale a negar tal autonomia: é uma lógica estranha acusar a Deus dos males do mundo para concluir daí que Ele não existe.

A conclusão que se segue destas afirmações é decisiva: na nova situação moderna o problema do mal requer uma mediação que faça justiça à sua nova figura secular. De saída, o mal não é um problema religioso mas simplesmente um problema humano universal. A resposta poderá ser ou não religiosa, mas só poderá ser abordada num segundo momento. $O$ tratamento, então, deverá ser articulado necessariamente em dois passos fundamentais para os quais achei por bem buscar duas palavras que permitam fixar a atenção e garantir a sua distinção:

1) O primeiro passo deve consistir numa ponerologia (do grego ponerós, mau), ou seja, um "tratado do mal" em si mesmo, como problema humano, estruturalmente prévio à dimensão religiosa, que nesse momento aparece só como uma das suas dimensões possíveis.

2) Sobre esse "tratado do mal" deverá ser articulado o segundo passo: a pisteodicéia (do grego pistis, fé) ou "justificação da fé" no sentido amplo: filosófica ou teológica, crente, agnóstica ou atéia. Nesta perspectiva a teodicéia tradicional se torna "pisteodicéia cristã", e a a-teodicéia tradicional - real, mesmo sem ser nomeada deverá apre-sentar-se como "pisteodicéia não-religiosa ou antireligiosa"3.

2 Idem, Beantwortung der Frage: Was ist Aufklärung? A482 e 492; Band XI, editado por W. WEISCHEDEL, Frankfurt a. M., 1978, 2a edição, pp. 53-61, aqui pp. 53 e 60.

${ }^{3} \mathrm{Na}$ base desta discussão sobre o problema do mal estão outros trabalhos mais amplos; cf. principalmente A. TORRES QUEIRUGA "Mal", in C. FLORISTÁN / J.-J. TAMAYO (Eds.) Conceptos Fundamentales del Cristianismo, Madrid, 1993, pp. 753-761; "El mal en perspectiva filosófica", in A.A. BOLADO et alii (Dirs.), Fe Cristiana e Sociedad Moderna, no 9, Madrid, 1986, pp. 178-194; idem, "Replanteamiento actual de la teodicea: Secularización del mal, 'Ponerología', 'Pisteodicea”', in M. FRAIJÓ / J. MASIÁ (Eds.), 


\section{2. "Unde malum?" A "ponerologia" como mediação indispensável}

\subsection{A armadilha do dilema de Epicuro}

A ponerologia permite defrontar-se - e este é um mérito inegável dela - com um pré-juízo fundamental: pressupor, como óbvia e indiscutível, a possibilidade de um mundo sem mal. É o que vem à tona no famoso dilema de Epicuro: "ou Deus pode e não quer evitar o mal, e então não é bom; ou não pode e quer, e então não é onipotente" ${ }^{\text {" }}$. É evidente que o dilema se apoia no pressuposto de que é possível um mundo sem mal, pois ninguém afirmaria que Deus deixa de ser onipotente por "não poder" fazer um "círculo quadrado", nem deixaria de ser bom se pudesse e não quisesse. É igualmente evidente que, com esse pressuposto, a teodicéia se torna impossível.

Nessas condições, o rigor e a honestidade lógica nos obrigariam a reconhecer que é impossível manter de forma coerente a fé em Deus. Com efeito, quando se leva a sério o caráter horrível do mal no mundo ninguém poderia sustentar a bondade de um "deus" que, podendo, não quisesse eliminá-lo. Quem gostaria de ser amigo de alguém que, olhando um hospital e tendo a possibilidade de curar a montanha de sofrimento que nele se esconde, se recusasse a fazê-lo não importa por que motivos? Que pessoa normal não evitaria, se pudesse, toda a fome, toda a violência, toda a dor, todas as tragédias que existem no mundo? A pergunta, então, parece inevitável: seremos nós melhores do que Deus? Em definitivo, seria ainda possível manter honestamente a fé num "deus" que se comportasse de uma forma, que, afinal, é pior do que a do mais malvado dos humanos?

As razões que, por acaso, fossem aduzidas depois chegariam irremediavelmente demasiado tarde. E só poderiam deixar a impressão de serem maus remendos ou inúteis remédios de urgência. Dizer, por exemplo, que Deus não evita o mal, mesmo que pudesse, mas demostra seu amor aceitando que seu Filho morra por nós na cruz é um argumento sem o mínimo rigor intelectual e extremamente frágil. Porque

Cristianismo e llustración: Homenaje al Prof. J. Gómez Caffarena, Madrid 1995, pp. 241292, resumido em A. TORRES QUEIRUGA, "EI mal inevitable: Replanteamiento de la Teodicea", Iglesia Viva 175/176 (1995) 37-69; "Mal y omnipotencia: del fantasma abstracto al compromiso del amor", Razón y Fe 236 (1997) 399-421 (ampliado em Del Terror de Isaac al Abbá de Jesús, Estella, 2000, pp. 165-245).

${ }^{4}$ A forma completa é: "Ou Deus quer tirar o mal do mundo, mas não pode; ou pode, mas não o quer tirar, ou não pode nem quer; ou pode e quer. Se quer e não pode, é impotente; se pode e não quer, não nos ama; se não quer nem pode, não é o Deus bom e, além disso, é impotente; se pode e quer - e isto é o mais seguro - , então de onde vem o mal real e por quê não o elimina?": O. GIGON (Ed.) Epicurus, Zürich, 1949, p. 80; LACTANCIO, De ira Dei, 13 [PL 7,121]. 
seria um amor que chegaria tarde demais e se limitaria a remediar um mal que poderia ter sido evitado: quando o "remédio" chegasse o mal já teria feito a sua devastação, além de continuar implacável na história. Daí ao cinismo é um passo só, como no conhecido ditado: "o senhor dom João de Robres,/ de caridade sem igual,/ fez este santo hospital/ como também fez os pobres"5.

Ao contrário, aceitar que Deus quer mas não pode conduz igualmente à incoerência. É o que tentou Voltaire ao dizer: "prefiro adorálo como limitado do que como mau"6. É o que em nossos dias repetiu Hans Jonas com o recurso a um Deus finito e não onipotente $^{7}$. A hipótese resulta cordialmente mais aceitável mas é igualmente absurda: um deus-finito é uma contradição. É com razão que Xavier Tilliette observa que tal concepção "parte de uma intenção comovedora mas de uma reflexão precipitada", uma vez que "é preciso saber a que se expõe um antropocentrismo que à miséria do homem acrescenta a impotência de Deus"8 .

A força do dilema é tão clara que alguém como Jean Pierre Jossua, não podendo negar essas duas conseqüências - porque equivaleria a negar quer a bondade quer a onipotência divinas -, apela para a incompreensibilidade, para o "não sabemos"9 . Tal recurso só pode ser

\footnotetext{
${ }^{5}$ Epigrama de Juan de Iriarte (1702-1771): cf. J. M. IRIBARREN, EI por qué de los dichos, Pamplona , 1994, 6a edição, pp. 251-252.

6 "Quando o único recurso que nos resta para o desculpar (a Deus) é confessar que seu poder não pôde triunfar sobre o mal físico e moral, certamente prefiro adorá-lo como limitado, a adorá-lo como mau": VOLTAIRE, Dictionnaire Philosophique, Paris, 1827 , t.2, p. 1589, apud A. HÜGLI, "Malum", in J. RITTER / K. GRÜNDER (Hrg.), Historisches Wörterbuch der Philosophie, Band 5, Darmstadt, 1980, p. 685.

${ }^{7}$ H. JONAS, Der Gottesbegriff nach Auschwitz: Eine jüdische Stimme, Frankfurt a. M., 1987.

${ }^{8} \mathrm{X}$. TILLIETTE, "Aporétique du mal et de la espérance", em M. OLIVETTI (Dir.) “Teodicea oggi?", Archivio di Filosofia 56 (1988) 431. J.B. Metz, de sua parte, pergunta se, definitivamente, se este tipo de discurso "não é simplesmente uma sublime duplicação do sofrimento humano e da impotência humana"; se não implica desconhecer a diferença de Deus, transferindo-Ihe o "mysterium negativo" próprio e exclusivo da criatura; e se, finalmente, isto "não conduz a uma perpetuação eterna do sofrimento": J.B. METZ, El clamor de la tierra. El problema dramático de la Teodicea, Estella 1996, pp. 20-21; cf. p. 19-23; assim como J.B. METZ / E. WIESEL, Esperar a pesar de todo, Madrid, 1996, pp. 61-64. E K. Rahner recorre ainda a uma expressão mais forte, quase brutal - "primitiva", diz ele, - afirmando que Deus não nos poderia livrar da lama se ele também não estivesse enterrado nela: "Um - einmal primitiv gesagt - aus meinem Dreck und Schlamassel und meiner Verzweiflung herauszukommen, nützt es mir doch nichts, wenn es Gott - um es einmal grob zu sagen - genauso dreckig geht": P IMHOF / H. BIALLOWONS, K. Rahner im Gespräch I: 1964-1977, München, 1982, p. 246. Cf. mais dados em J. SPLETT, Denken vor Gott: Philosophie als Wahrheits-Liebe, Frankfurt a. M.: 1996, pp. 297-299; A. KREINER, Gott im Leid: Zur Stichhaltigkeit der Theodizee-Argumente, Freiburg / Basel / Wien 1998, pp. 165-190.

9 J.-P. JOSSUA, “¿Repensar a Dios después de Auschwitz?”, Razón y Fe 233 (1996) 6573; o trabalho fora publicado no número de janeiro de 1996 da revista Études.
} 
justo com uma condição: que essa incompreensibilidade não venha antes do tempo, que seja fruto do mistério mesmo e não das nossas afirmações a respeito dele, concretamente do pressuposto de que é possível um mundo sem mal ${ }^{10}$. A prova está em que essa contradição desaparece quando se nega o pressuposto da possibilidade de um mundo sem mal.

A ponerologia precisamente coloca em primeiro plano esta questão: não pretende negar a priori essa possibilidade mas exige que ela seja discutida. O que nada tem a ver com "racionalismo". Trata-se de racionalidade elementar. Além do mais, pelo fato de situar o problema no plano da sua universalidade humana obriga a levar a sério a especificidade da fé (ou, no caso, do ateísmo). Porque o que está em jogo não é a fé mas sua interpretação. Do contrário estaríamos in-correndo no perigo - objetivamente evidente, embora subjetivamente não percebido em muitas discussões - de identificar sem mais com a fé o que foi uma posição tradicional e o seu pressuposto de um possível mundo sem mal. Esquecendo assim que, mesmo que fosse "tradicional", tal posição não deixava de ser uma interpretação como outra qualquer. E que, portanto, não pode ser atribuído ao "mistério da fé" o que, salvo prova em contrário, era resultado das suas próprias contradições.

\subsection{A impossibilidade de um mundo sem mal}

Esta questão é decisiva. E exigiria um estudo mais aprofundado. A falta de espaço, porém, me obriga a limitar-me a algumas indicações superficiais que, no fundo, nada mais são do que um convite ao leitor para que faça uma autêntica epoché (evpoch, ): trata-se de pôr entre parêntese as convicções espontâneas, que nos chegaram por mil caminhos da tradição, para "voltar à coisa mesma".

1) O primeiro alerta vem do que poderíamos chamar a imanentização moderna no modo de considerar o mundo. A palavra

\footnotetext{
${ }^{10}$ Porém a instabilidade desta solução é comprovada pelo fato de que pode acabar aceitando como válida uma postura ambígua como a do rabi Jossel Rashower. Ele, dando por suposto que os horrores do gueto de Varsóvia podiam ser evitados por Deus, pois obedecer a "esse tempo incompreensível em que o Todo-Poderoso desvia seu olhar dos que Ihe fazem súplicas", conclui: "Tu fizeste tudo para que eu não creia em ti! Mas morro exatamente como vivi: com uma fé inquebrantável em ti". (0 mesmo diz J.M.R. TILLARD "Sommes-nous les derniers chrétiens?", Esprit et Vie 106 [1996] 660-666; de ambos tomo referência). Porém já se vê que, sob uma piedosa aparência - subjetivamente sincera, sem dúvida - , esta solução pode resultar objetivamente ímpia, posto que pretendendo manter, apesar de tudo, a fé em Deus, acaba convertendo-o em moralmente inferior ao homem. Uma advertência que deveria ser levada muito em conta perante certas "modas teológicas", das quais, embora menos grave, eu não ex-cluiria a teoria do zimzum (ou o "encolher-se" de Deus para dar lugar ao mundo), que não soluciona nada e faz muito pouca justiça à idéia de Criação.
} 
pode ser estranha mas a sua significação é simples. De maneira espontânea, hoje, todos nós buscamos a causa de qualquer mal em realidades mundanas: quando há dor procura-se a ferida; diante de um assassinato busca-se o malfeitor; se há uma guerra (ou mesmo um gulag ou um "holocausto") é porque existem decisões sócio-políticas que a produzem. Ninguém iria explicar hoje esses acontecimentos pelo influxo de agentes extramundanos de tipo mágico, mítico ou religioso, como acontecia não faz ainda muito tempo. Na doença acudimos ao médico; pretender curá-la mediante uma bênção do sacerdote tem um sabor inevitavelmente arcaico. Resultaria muito estranho que hoje um historiador pretendesse explicar certos acontecimentos (mesmo quando são terríveis, como o "gulag" ou o "holocausto") recorrendo a influxos "demoníacos"11.

De fato, neste nível, a pergunta pela origem do mal remete hoje de maneira praticamente unânime ao próprio mundo: dado o que é o mundo e como funciona seria impossível que não se produzam nele dilacerações e conflitos quer no nível da história natural (lembremonos de Teilhard de Chardin) quer no nível da história humana. Bastaria passar os olhos pela bibliografia sobre o mal para aperceber-se que a resposta unânime a esta pergunta concreta é: num mundo tal como é e o conhecemos o mal é algo inevitável ${ }^{12}$.

2) Mas com isso a pergunta não está esgotada; ela retorna num segundo nível: dado que este mundo é impossível sem o mal, seria possível um mundo diferente no qual não houvesse conflitos, rupturas, crimes e sofrimentos, i.é. um mundo sem mal? Este é, sem dúvida, o núcleo mais duro do problema. Por isso é necessário proceder devagar na reflexão e estar atentos às possíveis armadilhas do preconceito.

A nossa imaginação dá como óbvia a resposta afirmativa: poderia haver um mundo sem mal. Assim imaginamos o paraíso na terra e aceitamos que tenha existido ou que venha a existir algum dia. É o que confirmam os mitos das religiões. A começar pela Bíblia. E o que prometem os sonhos da utopia, tão enraizados no nosso imaginário. Além

\footnotetext{
${ }^{11}$ Sobre esta mudança profunda na mentalidade e sua decisiva importância para a teologia, ocupo-me nos primeiros capítulos de Fin del cristianismo premoderno: Retos hacia un nuevo horizonte, Santander, 2000.

${ }_{12}$ Reconhece-o a partir da própria física, o livro, tão agudo como teologicamente dis-paratado, de J. F. TIPLER, La física de la inmortalidad: Cosmología contemporánea: Dios y la resurrección de los muertos, Madrid, 1996, pp. 330-336. Cita o "dilema do estudante", que vem desde a Idade Média: "Se Deus é onipotente, poderia fazer uma pedra tão pesada que nem Ele mesmo poderia levantar. Mas se nem Ele mesmo a pode levantar, então não é onipotente!". A isto responde com toda razão: "A onipotência de Deus não se encontra limitada pela habilidade humana de dizer tolices. A onipotência de Deus só significa que Ele pode realizar qualquer coisa que não seja logicamente impossível”: p. 333.
} 
do mais, como Freud nos ensinou, ela produz um feed-back contínuo nos nossos sonhos de onipotência infantil, que tanto resistem a ser curados pelo austero princípio da realidade. É fácil compreender, por isso, que essa "imaginação" esteja presente de maneira não reflexa em todas as discussões do problema. E que, de ordinário, reaja com a presteza e a segurança do que parece evidente diante de qualquer questionamento.

Tudo muda, porém, ao introduzir aí o "trabalho do conceito": nem tudo o que pode ser "imaginado" pode "ser pensado". Se a aparição do mal dependesse de alguma qualidade particular deste mundo conhecido sempre seria possível pensar num mundo sem essa qualidade e, portanto, sem mal. Mas o mal é tão profundo, variado e universal que qualquer tentativa de explicá-lo por uma qualidade particular está condenada ao fracasso. Leibniz foi o primeiro a iniciar este tipo de consideração, embora contaminado ainda por preocupações racionalistas $^{13}$. A sua genialidade consistiu precisamente em apontar para uma raiz universal que é inerente ao mundo como tal: a imperfeição originária da criatura. Ou seja, traduzido numa linguagem secularizada, a limitação e finitude do mundo.

Com efeito, se a raiz do mal está na finitude é impossível pensar um mundo sem mal. Porque qualquer mundo que possa existir será necessariamente finito. Poderão variar os seus elementos constitutivos e 0 modo de articulá-los, mas, por ser limitados, estarão expostos igual-mente ao choque e ao desajuste, às falhas e ao sofrimento. Estes efeitos seriam talvez diferentes na sua forma e qualidade dos que nós conhecemos, mas estariam igualmente marcados pelo que "não deveria ser". A seu modo seriam "maus". Diga-se de passagem que com isso não se afirma que 0 nosso mundo seja o único possível. (É muito provável que este conceito seja contraditório). A única coisa afirmada é que qualquer mundo possível tem que ser finito. $E$, por isso, exposto ao mal ${ }^{14}$.

\footnotetext{
${ }^{13}$ Cf. A. TORRES QUEIRUGA, "O diálogo Bayle-Leibniz acerca do mal: Unha encrucillada decisiva na historia do problema", in Simposio sobre el Pensamiento Filosófico y Político en la llustración Francesa, Santiago 1992, pp. 105-119; e a excelente ambientação do período subseqüente feita por A. VILLAR, Voltaire-Rousseau en torno al mal y la desdicha, Madrid, 1995.

${ }^{14}$ De fato surpreende a constatação de que a resistência em examinar o pressuposto leva continuamente a deformar esta nova proposta, inclusive por parte de amigos que, mesmo sem a compartilhar, deveriam ao menos tentar compreendê-la. J. A. Estrada, limitando sua exposição de minha postura à ponerología, faz-me supor que "a teodicéia não tenha nada a ver com Deus" ou que possa realizar-se "sem referência necessária à problemática religiosa": J. A. ESTRADA, La imposible teodicea. La crisis de la fe en Dios, Madrid 1997, p. 218; e, mais recentemente, L. M. Armendáriz atribui-me que "não cabe pensar que Deus pudesse fazer outro mundo senão este do qual fazemos parte": L. M. ARMENDÁRIZ, Hombre y mundo a la luz del Creador, Madrid, 2001, p. 261; cf. pp. 259-266, meu sublinhado; tinha-o já dito em ¿Pueden coexistir Dios y el mal? Una respuesta cristiana, Bilbao 1999, pp. 28-30).
} 
A dificuldade reside em mostrar que esta visão é correta. Não se trata evidentemente de "deduzir" o mal mas de "compreendê-lo" a posteriori, como um fato, um dado inerente à realidade tal como se apresenta ao nosso exame. $O$ que põe em relevo é o realismo desta proposta. E a renúncia consciente a entrar nas especulações do incontrolável debate sobre os "mundos possíveis", tão característico da literatura anglo-saxônica. Trata-se, sim, de indicar as linhas mestras que, a partir de ângulos muito diferentes, convergem nesta direção.

A experiência mais banal captou sempre que uma qualidade que "define" uma realidade finita expressa ao mesmo tempo o limite do que essa realidade não é. Ser homem, por exemplo, significa não ser mulher; e ser um círculo implica necessariamente não ser um quadrado. A sabedoria popular o expressou de mil formas: "para fazer a omelete é preciso quebrar os ovos", ou "nunca chove segundo o desejo de todos". Spinoza elevou esta constatação à dignidade de axioma metafísico: "toda determinação é [também] negação" 15 . E Hegel - que assume Spinoza ao citá-lo - acentuará a força deste princípio ao concebê-lo dinamicamente como o trabalho inevitável e doloroso do negativo na constituição da realidade.

É provavelmente por isso que esta nova convicção aparece sobre-tudo e com força irresistível nas formas de pensamento mais sensíveis ao histórico e ao evolutivo: nos idealistas, a seu modo, e, já totalmente definido, em pensadores como Bergson e Teilhard, para culminar, como é sabido, na filosofia do processo. Whitehead, por exemplo, acentua com energia que "mau" não é só o negativo e o que destrói mas também o "trivial", o que impede empobrece a realização dinâmica que aperfeiçoa o ser ${ }^{16}$. No fundo, a ausência de mal equivaleria a grau zero de realidade.

3) Mantendo-nos ainda neste nível não é difícil ver que estas afirmações se aplicam também à liberdade finita. Se a raiz do mal está na limitação, onde houver limitação aparecerá o mal. De acordo, naturalmente, com o tipo de realidade limitada. Subindo na "escada do ser", ao surgirem novos modos de afirmação da realidade aparecem tam-bém novos tipos de "mal": a doença surge com a vida, a dor supõe a sensibilidade. Com a liberdade nasce no mundo um novo modo de

\footnotetext{
15 "Omnis determinatio est negatio": B.SPINOZA, Epistolae, no L; in IDEM, Opera, editada por C. GEBHARDT, Heidelberg, 1924, t.4 p. 420; in idem, Oeuvres Complètes de Spinoza: texte nouvellement traduit ou revu, présenté et annoté par R. CAILLOIS / M. FRANCĖS / R. MISRAHI = Bibliothèque La Pleiade, no 108, Paris, 1954, p. 1231. ${ }^{16}$ Da bibliografia imensa a respeito, recomendo a lúcida e concisa síntese de J.B. COBB (Jr)./ D.R. GRIFFIN, Prozess-Theologie. Eine einführende Darstellung, Göttingen, 1977, pp. 67-74; com mais detalhe, B.L. WHITNEY, Evil and the Process God, New York, 1985 (ainda mais útil é sua síntese What are they saying about God and evil?, New York ,1989, pp. 47-57. 82-93).
} 
realidade, o mais alto, sem dúvida, dentro da realidade conhecida. Mas sendo também limitada, mostra igualmente seu peculiar tipo de "mal": a possibilidade do seu uso distorcido, o "mal moral"17.

Esta exposição é demasiado breve para um assunto tão complexo, mas procurando manter a pergunta dentro dos níveis propostos, não parece aventurado tirar esta conclusão geral: a realidade não é má pelo fato de ser limitada e finita, mas está inevitavelmente aberta ao "mal". E esse mal se torna presença efetiva como "mal físico" nas realidades naturais e como "mal moral" no âmbito da liberdade humana. Dito com outras palavras: é realmente impossível a existência de um mundo sem mal, tanto físico como moral, mesmo na hipótese de "outros mundos" possíveis (que sempre seriam finitos e limitados). Mais ainda, é preciso afirmar de maneira explícita que se trata de uma necessidade estrutural. "Pensar" um mundo sem mal equivale a "pensar" um círculo quadrado, ou seja, não pensar, mas simplesmente justapor palavras, corretas talvez do ponto de vista sintático mas desprovidas de qualquer sentido semântico.

Seria inútil objetar que, mesmo admitindo que o mal seja inevitável, o inadmissível seria o seu "excesso": a necessidade estrutural explicaria a existência do mal mas não de tamanho mal. Brota, contudo, espontaneamente a pergunta: "excesso" com relação a que? Porque na verdade o mal é sempre excessivo: o que ninguém quer, o que não deveria ser, o "injustificável" 18 . Se pudesse ser evitado seria tão injustificável o sofrimento de uma criança (Dostoiewsky e Camus) como o de uma guerra. Do ponto de vista estrutural esta objeção tem todas as características de retoque a um paradigma já esvaziado mas que não queremos inconscientemente abandonar.

\section{O mundo tem sentido? A pisteodicéia cristã}

Esta conclusão não significa que o discurso sobre o mal esteja encerrado. Pelo contrário, é agora que pode ser formulada a pergunta verdadeiramente humana: como viver num mundo no qual devemos

\footnotetext{
${ }^{17} \mathrm{E}$, naturalmente, também neste caso, convém insistir que não significa que finitude seja igual a maldade, mas a bem-finito, imperfeito; a liberdade não é sem mais culpável; o que acontece é que nem sempre está - nem pode estar - à altura de seu próprio ser; mas quando cai, cai por sua culpa, mesmo quando, simultaneamente, mostra-se também vítima de seus condicionamentos, de sua finitude.

${ }^{18}$ No caráter de "injustificável" tem-se insistido, sobretudo, acerca de certos males que ultrapassam os limites humanos, principalmente a propósito do Holocausto: cf. J. NABERT, Essai sur le mal, Paris, 1958, e, em geral, toda a literatura "after Auschwitz". Compreende-se, porque seu volume é pesado. Mas no fundo não faz mais que revelar o caráter intrínseco de todo mal, que é por si mesmo injustificável e que, por isso, não cabe na "lógica do para", mas somente numa parte do "apesar de".
} 
contar inevitavelmente com a terrível presença do mal? Que sentido pode haver para uma existência individual e para uma história universal que, de modo inevitável, comportam tanto sofrimento físico e tanta perversão moral, mais ainda, tanta vítima inocente e tanta dor irredenta? Quem terá a última palavra: o absurdo, o desespero ou, no máximo, a resignação? Ou ainda há lugar para o sentido e a esperança?

\subsection{A pergunta fundamental}

Por ser simplesmente humana, a pergunta é universal. Por isso são tão diferentes as maneiras de encarar as respostas. Respostas, e portanto autênticas formas de "fé", no sentido de opções radicais, de "cosmovisões" que se apoiam necessariamente em razões. Ou, dito de outra maneira, têm que justificar-se, são pisteodicéias. Justificações necessárias tanto para os que optam pela "náusea", como o primeiro Sartre, ou pelo absurdo que produz revolta, como em Camus, quer para os que optam pelo sentido, seja ele o nirvana budista ou a salvação cristã. Aqui nos concentraremos nesta última opção, procurando esclarecer a figura que deve revestir hoje a teodicéia como "pisteodicéia cristã". O ponto de partida é, pois, a pisteodicéia crente, que supõe a fé em Deus ${ }^{19}$, e mais concretamente a fé no Deus de Jesus que "é amor".

Antes de mais nada é preciso constatar com clareza a mudança fundamental que se opera na formulação da pergunta básica. A pergunta não é mais: "por que Deus criou um mundo com mal, tendo podido criá-lo sem mal?" (Já sabemos a estas alturas que essa proposição, apesar das aparências, é um nonsense, um absurdo que carece de sentido real). A pergunta agora deve ser: "por que Deus, sabendo que o mundo "criado" estaria marcado inevitavelmente pela ferida do mal, apesar de tudo o criou?" (Apesar do antropomorfismo, essa formulação ajuda a ver com clareza a questão).

Se quisermos levar a sério o Deus de Jesus, dois caminhos fundamentais se apresentam para responder a esta pergunta. Um é o caminho curto da fé no amor de Deus. Tal caminho se apóia diretamente

\footnotetext{
${ }^{19} \mathrm{O}$ presente discurso o dá por suposto. Mas é preciso ainda começar a partir de mais baixo, perguntando se o imenso problema que o mal coloca, em vez de levar à negação de Deus, como tantas vezes se pensa, não pode antes levar a sua afirmação. São Tomás o diz: Si malum est, Deus est. "se há mal, Deus existe" (Contra Gentiles 3, 71). De fato a mesma prova da contingência parece implicar isto; e o fazem ainda com mais clareza os discursos "teodicéicos" que, como o de J. B. Metz, socorrem às vítimas da história (cf., por exemplo J. B. METZ, El clamor de la tierra: El problema dramático de la Teodicea, Estella 1996). Porém não é possível entrar agora nesta questão.
} 
na confiança e está convencido de que as objeções, sejam quais forem, hão de ter uma resposta, mesmo quando ainda não se vê uma explicação. $O$ outro é o caminho longo que pretende "dar razão" dessa confiança (1Pe 3,15), libertando-a das contradições nas quais poderia ser envolvida pelo nosso discurso. Ambos caminhos são independentes, mas é inegável que existe uma circularidade hermenêutica entre eles. Apesar de tudo é conveniente distinguílos e levar muito a sério a tarefa que corresponde a cada um deles. A primeira é básica para a fé e por si só seria suficiente.

\subsection{0 "caminho curto" da fé em Deus como amor}

O caminho curto parte da confiança e recorre diretamente à lógica do amor. Se "Deus consiste em amar" (ho Theós agápe estín: I Jo 4,8.16) e nos criou por amor, parece evidente que tudo o que é oposto ao nosso bem se opõe identicamente a Ele. A fé viva compreende quase que por instinto que, se existe o mal no mundo não é porque Deus o queira ou o permita mas porque não pode ser de outra forma, porque é inevitável. Ao ver, por exemplo, uma criança sofrendo de câncer e junto dela a sua mãe, não é necessário um exercício lógico muito agudo para compreender que se trata de algo que a mãe não pode evitar. Ora, mesmo que aqui falhasse a lógica e a criança sofresse porque a mãe se esqueceu do fruto das suas entranhas, quando se trata de Deus não pode falhar. Há muito tempo que o profeta ousou, com toda justeza, pôr na boca de Deus as palavras decisivas: mesmo que uma mãe se esqueça do filho das suas entranhas, "eu não me esquecerei de ti" $($ Is 49,15$)$.

Dentro da lógica da fé esta conseqüência parece evidente. Confesso, por isso, que fico cada vez mais espantado vendo que boa parte da teologia continua resistindo a aceitar tal conclusão, mesmo com o risco de incorrer não só em contradições lógicas mas também em sérias incoerências religiosas. Há, contudo, uma explicação. Em primeiro lugar ficamos desorientados com 0 conceito abstrato da onipotência divina. A mãe - pensamos - é impotente, mas Deus poderia. E esse conceito é alimentado continuamente pelo desejo, ao qual já aludimos, de onipotência infantil ("papai pode tudo") e reforçado pela persistente mentalidade "mítica" de um contínuo intervencionismo divino no mundo.

De fato, valeria a pena o esforço para detectar a presença, mais ou menos explícita, deste argumento na tradição. Santo Agostinho, por exemplo, acaba utilizando-o ao afirmar: "pois o Deus Todo-Poderoso coisa que aceitam até os que não crêem, pois Ele tem o sumo poder sobre as coisas - sendo como é sumamente bom, não permitiria que houvesse nada de mal nas suas obras, a não ser porque sendo tão 
onipotente e tão bom é capaz de tirar o bem até do mal”,20. Leibniz é mais direto numa série de textos muito significativos, que podem ser resumidos na afirmação de que a bondade que vemos em Deus permite confiar mesmo no que não vemos dele ${ }^{21}$.

Tenho mesmo a convicção que tal argumentação pôde manter obscuramente a fé apesar das suas explicações insuficientes e mesmo contraditórias. Porque o dilema de Epicuro - tal como se apresentava e, infelizmente, continua a ser apresentado não poucas vezes - tornava impossível do ponto de vista lógico a defesa da fé. Contudo, um instinto mais forte do que a lógica fazia intuir aos que têm fé que a verdade do amor de Deus era mais forte do que as razões às quais aludia a lógica. Obrigados a fazer uma escolha optavam pela fé: pereat logica, dum fides salvetur (que sucumba a lógica desde que se salve a fé).

É o que justifica até certo ponto posições como as de Terrence W. Tilley $^{22}$ ou as de William C. Placher ${ }^{23}$ ao insistirem, provavelmente com razão, que o modo dos antigos formularem o problema era diferente, porque defendia a fé sem entrar expressamente nestas questões. Mas essa atitude era possível num ambiente não secular, que contava com o apoio da vivência comunitária e da plausibilidade social do cristianismo. Hoje, contudo, poderia transformar-se numa armadilha mortal. É suficiente revisitar os argumentos dos filósofos, ou simplesmente percorrer os artigos dos jornais por ocasião das grandes catástrofes naturais, para comprovar que essa contradição já tomou conta da consciência pública. Se partirmos do pressuposto que tais catástrofes poderiam ser evitadas, a conclusão é clara: ou Deus não existe, ou não pode ser bom nem poderoso. No novo contexto de uma mentalidade secular, refugiar-se como antigamente no "Deus pode tirar o

\footnotetext{
${ }^{20}$ S. AGOSTINHO, Enchiridion de fide, spe et caritate, cap. 3: “...neque enim Deus omnipotens - quod etiam infideles fatentur: rerum cui summa potestas - cum summe bonus sit, ullo modo sineret mali esse aliquid in operibus suis nisi usque adeo esset omnipotens et bonus ut bene faceret et de malo".

${ }^{21}$ Cf. W. LEIBNIZ, Essais de Théodicée, Die philosophischen Schriften von Gottfried Willhelm Leibniz, VI [1885], editado por C.J. GERHARDT, Hildesheim, 1965, pp. 187-188; cf. pp. 70-72. 108-109. 183. 244-245. 248. 385. Insiste corretamente neste ponto A. PEPERZAAK, "Dieu et la souffrance à partir de Leibniz", in M. OLIVETTI (Dir.) “Teodicea oggi?", Archivio di Filosofia 56 (1988) 51-74, principalmente pp. 71-73 e G. ZINGARI, "Pensiero di Leibniz e linguaggio della Teodicea", ibidem, pp. 85-96, que mostra que em Leibniz o metafórico é muito mais importante do que parece.

${ }^{22}$ T.W. TILLEY, The Evils of Theodicy, Washington D. C., 1991.

${ }^{23}$ W.C. PLACHER, The Domestication of Transcendence: How Modern Thinking about God Went Wrong, Louisville, 1996. Sintetiza assim: "Em contraste com o pleiteamento da teodicéia, esta me parece a melhor coisa que a fé cristã diz às vítimas do sofrimento:

1) não compreendo e não posso imaginar por quê estás sofrendo desta maneira, mas 2) creio que Deus não te esqueceu e que tu definitivamente não estás privado do amor de Deus", p. 206.
} 
bem do mal" é insuficiente, porque mostrando as contradições dessa lógica há o perigo de que desabe também a fé. Infelizmente sobram e continuarão sobrando os exemplos. Por isso se torna indispensável complementar este caminho com o caminho longo.

\subsection{0 "caminho longo" através da ponerologia}

Como já foi dito, a ponerologia, ao obrigar a reformular a pergunta, faz explodir o dilema de Epicuro: se é uma contradição pensar um mundo sem mal, o desafio que ele apresenta não tem mais sentido e saltam em pedaços os pólos da alternativa.

Desfaz-se, com efeito, a primeira parte: a (aparente) contradição entre o mal e a onipotência. Porque "onipotência" é vox relativa, i.é. poder-fazer significa necessariamente poder-fazer-alguma coisa. Ora, se essa "alguma coisa" não existe é absurdo falar, a respeito dela, de poder ou não-poder. Afirmar que Deus "não pode" fazer círculos-quadrados ou ferro-de-madeira ou um mundo finito-perfeito nada põe nem tira da sua onipotência; apenas enuncia que não existe o objeto sobre o qual poderia ser exercida a onipotência ${ }^{24}$. Talvez um exemplo muito simples pode ser iluminador: que uma mulher, excelente mãe e professora de matemática, "não possa" ensinar trigonometria ao seu filhinho de um ano, não depõe contra o conhecimento ou a capacidade pedagógica dessa mulher; é simplesmente uma afirmação sobre a in-capacidade do menino.

Desaba igualmente a segunda parte do dilema que questiona a bondade. Não é por falta de amor que a mãe, no exemplo anterior, não ensina trigonometria à criança; trata-se simplesmente de uma impossibilidade objetiva. De modo semelhante, ao mostrar que o mal é inevitável por causa da finitude da criatura, a ponerologia permite compreender que tal fato não contradiga o amor de Deus. É verdade que 0 mistério permanece e que a pergunta brota imediatamente: então, por que Deus criou a criatura apesar do mal? A ponerologia, contudo, pode manter a sua coerência e obriga a uma compreensão mais pro funda pelo simples fato de situar a pergunta no seu devido lugar, sem perder nada do realismo nem esconder a cabeça diante da dureza das objeções.

\footnotetext{
${ }^{24}$ É curioso como Santo Anselmo afirma ainda mais: este aparente "não poder", que nasce do verdadeiro ser da onipotência, não só não a nega, mas a afirma absolutamen-te: "Quoniam namque dicitur Deus non posse, nulla negatur in illo potestas, sed insuperabilis significatur potentia et fortitudo": S. ANSELMO, Cur Deus homo I. 2, c. 17; Obras Completas de san Anselmo I = BAC no 82, Madrid, 1972, p. 872; merece ser lido todo o capítulo.
} 
Este seria o lugar adequado para começar a repensar todos os grandes temas teológicos apresentando-os sob uma nova luz. Não esqueçamos que estamos nos movimentando já no âmbito da fé, dentro da pisteodicéia cristã. Mas essa seria uma tarefa impossível agora; é, contudo, possível oferecer algumas pistas.

\subsection{Alguns temas a partir desta nova visão}

Comecemos pela criação. A nova perspectiva vira pelo avesso a objeção: o mal nos permite tomar consciência do imenso amor que supõe a criação. Poderíamos dizer - mesmo conscientes do crasso antropomorfismo - que Deus "complicou a sua vida". A criação só tem sentido como expressão do amor infinito que deseja comunicar a sua felicidade ${ }^{25}$. Mas decidir criar-nos, apesar de conhecer todas as dificuldades, dores e revoltas das criaturas, significava para Deus comprometer o seu amor e expor-se ao imenso trabalho da "compaixão". O exemplo dos pais quando decidem trazer um filho ao mundo pode ilustrar a afirmação anterior ${ }^{26}$. E, acima de tudo, a história da salvação mostra como a consciência religiosa soube descobrir muitas vezes apesar das teorias - que a presença de Deus na história só tem sentido como amor, preocupação, cuidado e luta continua pelo nosso bem.

A história não se nos apresenta, então, como uma "prova" da qual Deus poderia nos ter livrado mas à qual nos submete para conceder-nos como "prêmio" a salvação. A história constitui simplesmente a condição de possibilidade necessária para que o dom da salvação nos possa ser concedido. A razão é clara: para nos "salvar", i.é. para nos introduzir numa plenitude e felicidade definitivas, Deus tinha que nos fazer existir primeiro, e existir como seres finitos, como seres que crescem e se realizam como tais na história da sua liberdade.

\footnotetext{
${ }^{25}$ Procurei demonstrá-lo sobretudo em Recuperar la creación. Por una religión humanizadora, Santander 1997, principalmente, c.2, 69-108.

${ }^{26}$ Com efeito, talvez não disponhamos de melhor símbolo humano que o da paternidade e o da maternidade responsáveis: pais honestos e conscientes estão diante de dilema semelhante quando se trata de trazer um filho ao mundo: ou não o fazem, escolhendo a pura negatividade do não ser, ou, se o fazem, têm que contar com a inevitável exposição ao mal; inclusive, no pior dos casos, terão que expor-se à tremenda repreensão "por quê me gerastes?" Quando se decidem, mesmo contando com as inevitáveis e enormes ambigüidades que possam interferir, reconhecemos que o fizeram por amor ao filho, mesmo que este possa complicar-Ihes a vida. E não exigiremos deles a responsabilidade pelo mal que lhe possam causar; esperaremos, isto sim, que com o mesmo amor se movam a acompanhá-lo e apoiá-lo. Quanto a Deus, está claro que não é exatamente igual; mas só a fantasia de uma onipotência abstrata impede ver que por seu vértice a comparação aponta para uma verdade comum; e, aqui sim, sem a possível ambigüidade do egoísmo num Ser que é tudo e tem tudo e que, portanto, só sabe, pode e quer dar: de novo, a intuição de Deus como agápe, como amor gratuito e doado.
} 
No que diz respeito ao ser divino, esta perspectiva opera também uma virada radical. A onipotência não pode mais ser imaginada como um intervencionismo arbitrário que, aparentemente solucionaria tudo mas, na verdade, anularia a consistência do mundo e a autonomia da liberdade. Agora pode ser vista no seu verdadeiro significado: a compaixão solidária de Deus que está sempre ao nosso lado contra o mal; um mal que não pode ser eliminado da história mas contra o qual Deus luta junto conosco, na esperança segura da realização final. E a bondade não é bonacheirice que se substitui ao nosso ser e supre a nossa liberdade, mas amor que nos sustenta, nos impulsiona e nos potencializa com um respeito extremo às nossas próprias decisões.

A cruz, por sua vez, não é um decreto divino nem o "preço" que Deus exige mas algo terrível que, como Jesus, o Pai tem que suportar porque lhe é imposto pela finitude e pela malícia de liberdades humanas que não aceitaram deixar-se impulsionar para o bem. Por isso, na cruz, ○ Pai não "abandona" Jesus mas o acompanha mais do que nunca $^{27}$. A ressurreição igualmente adquire todo o seu sentido: não rompe a história, porque se realiza plenamente para além da morte, mas mostra como, apesar de tudo, a existência vale a pena porque Deus acaba resgatando-nos do $\mathrm{mal}^{28}$.

Seria possível continuar falando ainda de temas como o pecado original, o inferno, o processo da revelação ou o milagre ${ }^{29}$. Mas é melhor talvez insistir no fundamental: esta visão do mal requer uma inversão radical das perspectivas. A partir dela se torna claro o que deveria sê-lo desde o começo: o primeiro a empenhar-se na luta conta o mal é Deus e não nós; por isso Ele está solicitando, continuamente e sem se cansar, a nossa colaboração. Só a cegueira objetivante do nosso olhar foi capaz de não deixar ver o evidente: um Deus que se manifesta compadecendo-se do mal de um povo oprimido e solicita a colaboração de Moisés; que, depois, sobretudo através dos profetas, não se cansa de repetir a mesma solicitude; que, finalmente, em Jesus resume tudo no único encargo do amor: um amor nada ideal mas tão concreto como a luta contra a fome, o cárcere ou a nudez.

Neste sentido adquire enorme importância o tema da oração de petição. Continuar pedindo a Deus diante do mal do mundo que "es-

\footnotetext{
${ }^{27}$ As teologias da cruz, como as de Barth, Jüngel, von Balthasar ou Moltmann da cruz como "um assunto entre Deus e Deus" - deveriam ser muito mais cuidadosas neste delicadíssimo ponto.

${ }^{28}$ Analiso isto com mais detalhe em dois trabalhos recentes, em vias de publicação: Gloria de Dios en la vida humana en un mundo de crucificados: Conferencia en la Facultad de Teología, em Recife, e "Ponerología y resurrección: el mal entre la filosofía y la teología", Revista Portuguesa de Filosofía; mais amplamente no livro em prepa-ração, Repensar la resurrección.

29 Digo algo nos trabalhos citados acerca da retomada atual da teodicéia.
} 
cute e tenha piedade" é objetivamente - independentemente das intenções subjetivas - uma perversão das relações: é como se pretendêssemos "lembrar a compaixão" a Deus que é quem suscita em nós a compaixão pelo próximo ou como se tentássemos convencer-lhe que "seja compassivo" quando é Ele que nos convoca sem se cansar para que colaboremos com Ele contra a dor dos seus filhos e filhas ${ }^{30}$.

\section{4.- A salvação final: enorme objeção e extrema possibilidade}

Insinuadas apenas algumas conseqüências, chegou o momento de enfrentar uma dificuldade que, com certeza, terá emergido já em mais de uma mente e que constitui, sem lugar a dúvidas, a maior objeção contra o princípio fundamental de todas esta maneira de formular o problema. Ela nasce justamente da fé na salvação final: então continuaremos a ser finitos e, no entanto, estaremos livres do mal. Isso pareceria anular tudo o que foi obtido com a ponerologia ${ }^{31}$ - A tentativa de dar-lhe uma resposta mais pormenorizada exigiria muitas páginas. Algumas indicações serão suficientes para insinuar o caminho da solução.

É preciso advertir, em primeiro lugar, que a pisteodicéia é o único lugar legítimo da objeção. Pela simples razão que a bem-aventurança ou salvação escatológica pertence à resposta religiosa e, portanto, pressupõe a fé. Não se trata de um dado óbvio, uma espécie de ponto de partida para pôr em questão uma evidência filosófica. Pelo contrário, trata-se de um mistério verdadeiro mistério agora, e para todas as teorias - com o qual nos deparamos. E a ele mesmo cabe buscar a sua possível inteligibilidade, mesmo que seja de maneira hesitante, difícil e obscura.

De qualquer maneira, para a "pisteodicéia" cristã a objeção é pertinente e deve ser enfrentada. Com os recursos, naturalmente, da ló-gica específica da teologia que, neste caso, busca antes de tudo uma "certa inteligência" analógica. Ou seja, mostrar, por um lado, que a

\footnotetext{
${ }^{30}$ Cf. A. TORRES QUEIRUGA, "Más allá de la oración de petición", Iglesia Viva 152 (1991) 157-193; com algumas variações: "A oración de petición: de convencer a deixarse convencer", Encrucillada 83/17 (1993) 239-254 e um pouco mais amplamente no livro Recuperar la creación: Por una religión humanizadora, Santander 1998, 2a edição, c. 6, pp. 247-294.

${ }^{31}$ E. Schillebeeckx, por exemplo, dá como óbvia a validez irrefutável desta objeção, apesar de situar expressamente a raia do mal na finitude da criatura: "La finitud no implica por sí misma sufrimiento y muerte. Si así fuese, la fe en una vida superior y supraterrena - que no deja de ser una vida de seres finitos - sería una contradicción intrínseca. Las creaturas nunca serán Dios": E. SCHILLEBEECKX, Cristo y los cristianos, Madrid, 1982, p. 818); muitos autores a repetiram.
} 
objeção é sensata, i.é. tem as suas razões e não é absurda; e, por outro lado, introduzi-la na interação positiva de sentido que se estabelece entre os diversos elementos no mundo da fé. Nesta perspectiva, a tarefa, mesmo sendo difícil não é impossível ${ }^{32}$.

É surpreendente que a primeira resposta remonte já a Santo Ireneu de Lyon, no século II. Não é por acaso que, entre os Padres da Igreja, é ele o que possui um sentido mais dinâmico e "histórico" da salvação e da fé. Colocado diante de uma questão semelhante - porquê aconteceu tão tarde a vida do Salvador? - ele responde com a necessária mediação do tempo e da sua "pedagogia" na constituição da realidade finita. Nem tudo o que é possível no fim é possível desde o início. Por exemplo, a mãe, não pode dar de comer carne a uma criança de peito, mesmo que invista nisso todo o seu carinho ${ }^{33}$. A pessoa é o que se torna, o que ela chega a ser no lento e livre amadurecimento da sua própria história. Levar a sério na sua radicalidade essa afirmação equivale a aceitar que a criatura não poder ser criada na sua perfeição completa, na glória final: um homem ou uma mulher que fossem criados adultos instantaneamente, constituídos de uma vez só na claridade da consciência, seriam algo fantasmagórico, "aparições" sem consistência, inclusive para si mesmos; não seriam eles mesmos. Seriam uma contradição ${ }^{34}$.

A insistir com tanta ênfase na liberdade, a cultura moderna tornou evidente essa condição da pessoa. $O$ que mais impressiona, contudo, é constatar que, muito tempo antes, não só Irineu mas "a grande tradição, desde o começo da patrística até Tomás, prolongando-se para além dele" negou que Deus pudesse criar uma liberdade finita mas já perfeita $^{35}$. Hans Urs von Balthasar, referindo-se a essa tradição, conclui: "a criação no estado de uma visão sobrenatural de Deus pressuposta na liberdade, mesmo que fosse a de um anjo atemporal, é intrinsecamente contraditória" ${ }^{\text {36 }}$. 0 tempo da história, pois, não é uma opção de Deus; como se Ele tivesse podido criar-nos felizes e não tivesse querido, quer para submeter-nos a uma "prova" (!), quer por qualquer outro motivo ou finalidade ${ }^{37}$. Trata-se, antes, de uma neces-

32 Num desenvolvimento mais amplo o afirmei em Creo en Dios Padre, Santander 1992, 3a edição, pp. 145-149; aqui matizo um pouco mais e resumo esquematicamente.

${ }_{33}$ S. IRENEO DE LIÓN, Adversus Haereses, IV, 38, 1.

${ }_{34}$ A este respeito faz obsevações profundas W. PANNENBERG, Systematische Theologie III, Göttingen, 1993, pp.691-694.

${ }_{35}$ Cf. H. de LUBAC, Surnaturel, Paris, 1946, p. 189; cf. pp. 187-321.

36 H.U. von BALTHASAR, Theodramatik IV, Einsiedeln, 1983, p. 362; cf. idem, Theodramatik II/1, Einsiedeln, 1976, pp. 195-201.

${ }_{37}$ Aqui se constata certa debilidade na excelente obra de J. HICK, Evil and the God of Love, London 1978, 2a edição, que, com sua teodicéia de tipo "ireneano", defende uma postura muito afim àquela aqui apresentada. Usando de uma metáfora de John Keats, fala do mundo como "o vale onde são feitas as almas" (... the vale of soul-making...: J. HICK, Evil and the God of Love, p. 259 nota 1), isto é, como condição de possibilidade para que as pessoas se realizem; mas não distingue com cuidado os planos 
sidade intrínseca da nossa constituição como seres finitos: ou somos assim ou não podemos ser em absoluto ${ }^{38}$. Numa palavra: se criandonos por amor e, portanto, unicamente para nossa felicidade, Deus não nos criou já completamente felizes é simplesmente porque era impossível.

É possível nessas condições imaginar uma salvação perfeita? Essa pergunta brota dos últimos contrafortes de uma razão que, situada no seio da experiência religiosa, dela acolhe certas intuições que a ultrapassam na direção do mistério. São intuições que nascem nela - do contrário não teriam nada de humano nem comunicariam algum significado - mas que a obrigam a dilatar-se na direção de algo que, em definitivo, é incompreensível: rationabiliter comprehenditur incomprehensibile esse ${ }^{39}$. Nessa dilatação despontam aqueles traços que impedem a contradição e apoiam a sua peculiar inteligibilidade. Concretamente dois serão indicados aqui.

O primeiro nasce, em certo sentido, da mesma dificuldade: do caráter dinâmico da liberdade. Esse traço que, na sua raiz originária, exige à liberdade construir-se a si mesma através de uma história exposta inevitavelmente a erros e deficiências, a revela também como aspiração infinita, que não se pode contentar com nada limitado, aberta a uma plenitude sem falhas ${ }^{40}$. A pessoa aparece assim numa tensão única e muito peculiar que qualifica a dinâmica da sua finitude até introduzi-la de algum modo no âmbito da infinitude. Com base no que há de mais dinâmico no pensamento de Santo Tomás, B. Welte fala a este respeito de "infinitude finita" (endliche Unendlichkeit) ${ }^{41}$.

Esta reflexão nos permite captar a seriedade da finitude e a impossibilidade de que ela possa atingir a plenitude por si mesma nas condições limitadas da história. Contudo, essa dialética, tão única e extrema, insinua uma outra possibilidade: a de acolher que a plenificação lhe possa ser dada gratuitamente rompendo os limites da história.

(secular e teológico) e tende a mesclar elementos finalísticos que debilitam a conseqüência de sua postura (Deus sempre poderia dispor de outros meios para os mesmos fins ou renunciar a eles) e que, de fato, tornam-se vulneráveis aos ataques.

${ }^{38}$ Talvez aqui caberia uma profunda consideração sobre a luta de Heidegger com o tema "ser e tempo" I "tempo e ser", que até certo ponto articula suas duas épocas principais. Em todo caso, parece que permanece firme a intuição: "o Ente é tempo" (e talvez também: "O Ser dá tempo"). Um tema fascinante.

${ }^{39} \mathrm{Na}$ necessidade de ampliar o que a teodicéia impõe à razão, insiste W. SPARN, "Mit dem Bösen leben. Zur Aktualität des Theodizeeproblems", in C. COLPE. / W. SCHMIDT-BIGGEMANN (Hrsg.), Das Böse. Eine historische Phänomenologie des Unerklärlichen, Frankfurt a. M., 1993, pp. 204-228, em particular às pp. 225-226.

${ }^{40}$ É, em definitivo, a tese de M. Blondel, em L'Action, tão presente em K. Rahner e em todo o "tomismo transcendental".

${ }^{41}$ B. WELTE, Über das Böse: Eine theologische Untersuchung, Freiburg / Basel / Wien 1959, pp. 15-17. 
Não se trata de um recurso engenhoso. De fato, essa foi desde sempre a intuição das religiões, i.é. da razão humana na sua "função religiosa". Concretamente, a religião bíblica afirma simultaneamente que "não se pode ver a Deus sem morrer" (Ex 23,20) e que o "veremos" na comunhão infinita $^{42}$. Além disso, já vimos como a mesma estrutura do mal, que mesmo "sendo" aparece como "o que não deveria ser", parece encerrar também essa promessa, pelo menos como uma possibilidade que não pode ser descartada a priori.

É possível ainda dar mais um passo, partindo da experiência do amor como comunhão pessoal (a mais sublime e a mais íntima das experiências humanas). Nessa experiência, a maravilha única que é a "reciprocidade das consciências" o que é do outro é meu e o que é meu é do outro. Desde a sua juventude Hegel tentou desvelar essa reciprocidade na sua profundidade especulativa, deixando entrever como, na comunhão com Deus, se torna possível esta última realização do homem:

Porque o amor é estabelecer uma diferença entre dois que, contudo, não são simplesmente diferentes entre si. 0 amor é a consciência e o sentimento da identidade entre esses dois, de existir fora de mim e no outro: eu não tenho a minha autoconsciência em mim mas no outro; mas esse outro - o único no qual estou satisfeito e pacificado comigo (...) - na medida em que ele, por sua vez, está fora de si, só pode ter a sua autoconsciência em mim, e ambos só podemos ser esta consciência de estar fora de nós e de nos identificarmos: somos esta intuição, sentimento e saber da unidade ${ }^{44}$.

Não me consta que Hegel tenha aplicado expressamente esta reflexão ao problema que nos ocupa. Por isso é mais surpreendente ainda

\footnotetext{
42 Uma tensão consciente, que inclusive se torna temática: "Ainda não se manifestou o que seremos. Sabemos que quando se manifestar seremos semelhantes a Ele, porque $O$ veremos tal qual é", diz São João (1 Jo 3,2); e é bem conhecida a difícil e paradoxal dialética com que São Paulo aborda o tema da ressurreição, pois chega até mesmo a falar de "corpo espiritual" (1 Cor 15).

${ }^{43}$ Aludo ao livro, tão instrutivo a este respeito, de M. NÉDONCELLE, La réciprocité des consciences, Paris 1942.

${ }^{44}$ G.W.F. HEGEL, Lecciones sobre filosofía de la religión, t.3, Madrid, 1985, p. 192. Cf. idem, Escritos de Juventud, México 1978, pp. 261-166. 274-278. 335-338...); idem, Vorlesungen über die Ästhetik II, Frankfurt a.M., t. 14, pp. 154-159.182-190, que é onde amplia mais tais idéias. Sobre a intensa tradição e significado filosófico destas idéias, a partir do platonismo até Hölderlin e o romantismo, cf. D. HENRICH, Hegel im Kontext, Frankfurt a. M., 1975, 2a edição, pp. 9-40.

Sobre sua importância decisiva para a teologia, cf. J. GÓMEZ CAFFARENA, Qué aporta el cristianismo a la ética, Madrid, 1991 (que dá outras referências próprias); A. TORRES QUEIRUGA, "Amor: fundamento y principio; vulnerabilidad y solidez", Sal Terrae 81 (1993) 281-192 e M. CABADA CASTRO, La vigencia del amor. Afectividad, hominización y religiosidad, Madrid, 1994.
} 
ver São João da Cruz - um místico tão cauteloso do ponto de vista especulativo - dar esse passo com uma ousadia admirável. E ainda por cima referindo-se à experiência desta vida. Ele ousa afirmar não só que Deus entrega a alma a si mesma, mas que a alma também entrega Deus ao próprio Deus:

porque sendo ela (a alma) aqui uma só coisa com ele, de certo modo ela é Deus por participação; e, embora não de modo tão perfeito como na outra vida, é, como já foi dito, como sombra de Deus. E, sob este aspecto, pelo fato de ser sombra de Deus, por causa dessa substancial transformação, ela faz em Deus por Deus o que Ele faz nela por si mesmo, do modo como Ele o faz, porque a vontade dos dois é uma só, e assim é uma só a operação de Deus e dela. Daí que, da mesma forma que Deus se entrega a ela por livre e gratuita vontade, assim também ela, pelo fato de ter a vontade tanto mais livre e generosa quanto mais unida a Deus, está dando Deus ao mesmo Deus em Deus, e é verdadeira e total dádiva da alma a Deus. Porque assim vê a alma que verdadeiramente Deus é dela e que ela o possui com posse hereditária, com propriedade de direito, como filho adotivo de Deus, pela graça que Deus lhe fez de se dar a si mesmo a ela; por isso, sendo propriedade sua, ela o pode dar e comunicar a quem voluntariamente quiser; e assim o dá ao seu querido, que é o próprio Deus que lho deu a ela; dessa maneira ela paga a Deus tudo o que lhe deve, porque voluntariamente Ihe dá tanto quanto dele recebe" ${ }^{\text {45 }}$.

De fato, nos últimos contrafortes do ser, onde só é possível estar à espreita no "êxtase da razão" - como sublinharam Plotino e Schelling - se produz o que à primeira vista seria impossível: uma certa "infinitização" da pessoa finita ${ }^{46}$ porque, como anunciou Paulo, então "Deus será tudo em todos" (1Cor 15,28). Ora, isso só pode ser pensado a partir da intimidade única da relação Criadorcriatura. Nessa relação a diferença é, ao mesmo tempo, a identidade do non-aliud. Assim é mais fácil compreender porquê não há lugar para nenhum tipo de alienação (como aconteceria na hipótese impossível de uma criação em estado perfeito). A relação que constitui a criatura finita potencializa de maneira inaudita a própria identidade, e, portanto, a própria liberdade: a pessoa é plenificada a partir do que ela livremente escolheu ser.

\footnotetext{
${ }^{45}$ S. JUAN DE LA CRUZ, Llama de amor viva, canc. III, 78, em CRISOGONO DE JESUS et alii (Eds.), Vida y Obras de San Juan de la Cruz = BAC no 15, Madrid, 1964, 5a edição, p. 913.

46 Talvez, melhor, uma "eternização" como, para preservar mais claramente a diferen-ça, dizem K. BARTH, Kirchliche Dogmatik III/2, Zürich, 1959, 2a edição pp. 770-771) e E. JÜNGEL, Morte, Brescia, 1972, pp. 169-173). Do ponto de vista oriental talvez se possa esclarecer ainda mais, cf. R. PANIKKAR, El silencio del Dios, Madrid, 1970, 47-53. 71-80. 254-257.
} 
Eis por que caminhos o mistério do mal nos conduziu ao mistério do nosso destino. E, nele, ao mistério definitivo: o mistério de Deus que, apesar de tudo, é amor. Só amor e salvação.

\section{(Tradução de Alfonso Carlos Palácio Larrauri SJ)}

Andrés Torres Queiruga é doutor em Filosofia, pela Universidade de Santiago de Compostela, e em Teologia, pela Universidade Gregoriana - Roma. Atualmente é professor de Filosofia na Universidade de Santiago de Compostela e membro dos conseIhos editoriais das revistas Sal Terrae, Iglesia Viva e Corintios XIII e membro do conselho científico da Revista Portuguesa de Filosofia. É um escritor prolífico. Alguns de seus muitos livros e artigos já foram traduzidos em português. Entre as suas publicações, destacamos: Repensar la Cristologia: ensayos hacia un nuevo paradigma. Estella: Verbo Divino, 1996 (tradução brasileira das Edições Paulinas, 1999); Recuperar la creación: por unha relixión humanizadora, Vigo: SEPT, 1996 (trad. brasileira da Paulus, 1999); Do Terror de Isaac ó Abbá de Xesús, Vigo: SEPT, 1999 (trad. brasileira das Edições Paulinas, 2001); Fin del cristianismo premoderno: retos hacia un nuevo hori-zonte, Santander: Sal Terrae, 2000.

Endereço: e-mail: atorres@usc.es 